Nevşehir Bilim ve Teknoloji Dergisi Cilt 5(1) 27-34 2016

DOI: 10.17100/nevbiltek.56241

URL: http://dx.doi.org/10.17100/nevbiltek.56241

\title{
Şanlıurfa Koşullarında Yetiştirilen Bazı Kırmızı Mercimek (Lens culinaris Medik.) Genotiplerinin Verim ve Verim Öğelerinin Belirlenmesi
}

\author{
Ayşe Gülgün Öktem ${ }^{1, *}$ \\ ${ }^{1}$ Harran Üniversitesi, Ziraat Fakültesi, Tarla Bitkileri Bölümü, Şanlıurfa
}

Öz

Bu çalışma 2013-2014 ve 2014-2015 yetiştirme dönemlerinde Şanlıurfa koşullarında yürütülmüştür. Bu çalışma ile Şanlıurfa koşullarına uygun yüksek verimli kırmızı mercimek çeşitlerinin belirlenmesi amaçlanmıştır. Araştırmada 11 adet kırmızı mercimek çeşidi denenmiştir. Deneme tesadüf blokları deneme desenine göre 4 tekrarlamalı olarak kurulmuştur. Her iki yıl ve birleşik varyans analizine göre çeşitler arasında çiçeklenme gün sayısı, bitki boyu, bin tane ağırlığı ve tane verimi bakımından istatistiki olarak önemli farklılık gözlenmiştir. İki yılın ortalamasına göre; çiçeklenme süresi 117.6-127.9 gün, bitki boyu 37.3-45.1 cm, 1000 tane ağırlığı 33.55-46.10 g, tane verimi 72.82-186.16 kg/da arasında değişmiştir. En yüksek tane verimi Şakar çeşidinden (186.16 kg/da) elde edilmiştir. En düşük tane verimi ise Yerli Kırmızı çeşidinden elde edilmiştir (72.82 kg/da). Şakar, Altıntoprak, Tigris ve Evirgen çeşitleri her iki yıl da diğer çeşitlere göre daha yüksek tane verimi değerleri vermişlerdir.

Anahtar Kelimeler: Kırmızı mercimek, Şanlıurfa, verim, verim öğeleri, genotip

\section{Determination of Yield and Yield Characteristics of Some Red Lentil (Lens culinaris Medic.) Genotypes Under Sanliurfa Conditions}

\begin{abstract}
This study was conducted in 2013-2014 and 2014-2015 growing seasons under Şanliurfa conditions. This study was aimed to determination of high yield red lentil varieties in Şanlıurfa conditions. Experiment was established accordingly to randomised completed experimental design with 4 replicates. According to both of years and year combined variance analysis flowering period, plant height, thousand kernel weight and grain yield was found significant. According to average of years; flowering period varied from117.6 to 127.9 day, plant height from 37.3 to $45.1 \mathrm{~cm}$, thousand kernel weight from 33.55 to $46.10 \mathrm{~g}$ and grain yield from 72.82 to $186.16 \mathrm{~kg} / \mathrm{da}$. The highest grain yield was obtained from Şakar variety $(186.16 \mathrm{~kg} / \mathrm{da})$. The lowest grain yield was found at Yerli Kırmızı variety (72.82 kg/da). Şakar, Altıntoprak, Tigris and Evirgen varieties gave higher grain yield than other varieties.
\end{abstract}

Keywords: Red lentil, Sanliurfa, yield, yield characteristics, genotype

\footnotetext{
*e-mail: gulgunoktem@harran.edu.tr
} 
1. Giriş

Baklagiller havanın serbest azotunu bağlayabilme yeteneği sayesinde, kendi azot ihtiyacını karşılayabilmekte ve ekili bulunduğu alana $6.4-21.6 \mathrm{~kg} / \mathrm{da}$ arasında değişen miktarlarda saf azot bağlayabilmektedirler. Ayrıca toprağın fiziksel, kimyasal ve biyolojik özelliklerini iyileştirerek tarıma katkıda bulunmaktadırlar [1].

Mercimek içerdiği yüksek protein oranı (\% 23) yanında, demir, kalsiyum, A vitamini içeriği ile insan beslenmesinde önemli bir yere sahiptir [2]. Özellikle hayvansal gıdaların pahalı olduğu ya da hayvansal proteinlerin tüketiminin sınırlı olduğu durumlarda, hayvansal gıdalara alternatif olarak kullanılabilmektedir. Ayrıca samanının besleyici oluşu ve hayvanlar tarafından sevilerek yenmesinden dolayı hayvan beslenmesinde de kullanılmaktadır. Mercimek köklerindeki rhizobium bakterileri sayesinde havanın serbest azotunu toprağa bağlamakta, toprak verimliliğini arttırmaktadır. Ayrıca ekim nöbetine girerek nadas alanlarının azaltılmasına katkıda bulunmaktadır.

Kırmızı mercimek Türkiye'de ve Güneydoğu Anadolu Bölgesi’nde önemli bir tarım ürünüdür. Kırmızı mercimek Türkiye'de 2.074.690 da alanda ekilmekte olup, 340.000 ton üretilmekte ve $164 \mathrm{~kg} / \mathrm{da}$ ortalama verim alınmaktadır. En fazla Güneydoğu Anadolu Bölgesi’nde üretilmekte olup, 2.009.955 da alanda ekilmekte 331.574 ton üretim sağlanmakta, $165 \mathrm{~kg} / \mathrm{da}$ ortalama verim elde edilmektedir. Güneydoğu Anadolu Bölgesi içinde yer alan ve yine bu bölgede en fazla ekim alanına sahip olan Şanlıurfa'da ise kırmızı mercimek 993.279 da alanda ekilmekte, 129.732 ton üretim elde edilmekte ve $131 \mathrm{~kg} / \mathrm{da}$ ortalama verim sağlanmaktadır [3].

Güneydoğu Anadolu Bölgesi’nde kırmızı mercimek tarımı genellikle sulanmayan alanlarda, yağışa bağlı olarak yapılmaktadır. GAP Projesi’nin tamamlanması ile birlikte sulanabilen alanlarda mercimek, ekim nöbeti sistemi içerisinde yer alacaktır. Şanlıurfa koşullarına uygun yüksek verimli mercimek çeşitlerinin belirlenmesi oldukça önemlidir. Ön bitki olarak uygun mercimek çeşitleri kullanıldığında ikinci ürün olarak yetiştirilebilecek diğer bitkilerle ekim nöbetine girebilecektir. Ayrıca, tarla tarımı içerisinde bir baklagil bitkisi olan mercimeğin yer alması toprak yapısının iyileştirilmesi, organik madde miktarının yükseltilmesi ve sürdürülebilir tarım açısından oldukça önemlidir.

Konu ile ilgili yapılan bazı çalışmalarda Fırat-87 çeşidinin geç olgunlaştığı, Şakar çeşidinin ise erkencilik, tane iriliği ve verim yönünden üstün olduğu bildirilmiştir [4]. Tohum verimindeki varyasyonun \% 80'inin iklimden kaynaklanabileceği açıklanmıştır [5]. Kahramanmaraş ve Şanlıurfa koşullarında en düşük tane veriminin Emre, en yüksek tane veriminin ise F90.41L genotipinden elde edildiği bildirilmiştir [6]. Van'da yapılan bir çalışmada, çeşitlere ait verimlerin 33-68 kg/da arasında değiştiği, Yerli Alaköy, Kırmızı-51 ve Erzurum-89 çeşitlerinin, yüksek verimli olduğu belirtilmiştir [7]. Amik Ovası koşullarında denenen bazı hatlara ait verimlerin 43.60-131.16 kg/da arasında değiştiği ve Hatay ili ve Türkiye ortalamasının üzerine çıktığı belirlenmiştir [8]. Bu çalışma ile Şanlıurfa koşullarına uygun, yüksek verimli kırmızı mercimek çeşitlerinin belirlenmesi amaçlanmıştır.

\section{Materyal ve Metot}

Araştırma, 2013-2014 ve 2014-2015 yetiştirme sezonunda Şanlıurfa koşullarında yürütülmüştür. Ekimden önce deneme alanından toprak örneği alınarak analiz edilmiş, bazı kimyasal özellikler ile 
toprağın azot, fosfor, potasyum içeriği belirlenmiştir. Her iki deneme yılına ait iklim verileri Tablo1, toprak özellikleri ise Tablo 2'de verilmiştir.

Tablo 1. Araştırmanın yürütüldüğü yıllara ait Şanlıurfa İli’nin bazı iklim verileri

\begin{tabular}{|c|c|c|c|c|c|c|c|c|c|c|}
\hline Yll & Parametreler & $1 *$ & 2 & 3 & 4 & 5 & 6 & 10 & 11 & 12 \\
\hline \multirow{5}{*}{$\stackrel{m}{\stackrel{\sim}{\sim}}$} & Mak. Sic. $\left({ }^{0} \mathrm{C}\right)$ & 16.4 & 19.5 & 24.9 & 34.3 & 36.4 & 41.5 & 32 & 27.0 & 16.9 \\
\hline & Min. S1c. $\left({ }^{0} \mathrm{C}\right)$ & -3.0 & 2.9 & 0.8 & 7.8 & 11.7 & 17.3 & 10.8 & 5.7 & -2.5 \\
\hline & Ort. sicaklık $\left({ }^{0} \mathrm{C}\right)$ & 6.8 & 9.3 & 12.9 & 18.4 & 22.9 & 29.0 & 32.0 & 27.0 & 16.9 \\
\hline & Ort. nispi nem(\%) & 69.5 & 73.6 & & 44.9 & 43.4 & 24.0 & & 57.5 & 54.6 \\
\hline & Top. Yağış (mm) & 86.8 & 107.2 & 12.1 & 18.0 & 56.2 & & & 19.5 & 76.7 \\
\hline \multirow{5}{*}{$\underset{\sim}{\stackrel{\nabla}{\sim}}$} & Mak. Sic. $\left({ }^{0} \mathrm{C}\right)$ & 18.0 & 22.1 & 24.7 & 30.8 & 38.7 & 40.1 & 31.9 & 22.8 & 17.0 \\
\hline & Min. Sic. $\left({ }^{0} \mathrm{C}\right)$ & 2.4 & -1.1 & 2.2 & 3.6 & 12.4 & 15.3 & 9.5 & 4.8 & 2.5 \\
\hline & Ort. sicaklık $\left({ }^{0} \mathrm{C}\right)$ & 8.6 & 10.0 & 14.2 & 18.5 & 24.0 & 28.4 & 20.3 & 12.1 & 9.5 \\
\hline & Ort. nispi nem(\%) & 65.6 & 44.0 & 51.7 & 47.5 & 29.8 & 26.4 & 49.5 & 53.9 & 79.4 \\
\hline & Top. Yağış (mm) & 44.3 & 20.8 & 91.6 & 33.3 & 6.0 & 20.6 & 25.7 & 78.6 & 55.4 \\
\hline \multirow{5}{*}{$\stackrel{\text { 늉 }}{\stackrel{\nu}{N}}$} & Mak. Sic. $\left({ }^{0} \mathrm{C}\right)$ & 17.2 & 18.2 & 24.8 & 29.9 & 36.9 & 38.4 & 33.0 & 24.3 & 20.0 \\
\hline & Min. Sic. $\left({ }^{0} \mathrm{C}\right)$ & -3.1 & -0.6 & 2.5 & 4.7 & 11.8 & 16.7 & 12.7 & 6.8 & 0.5 \\
\hline & Ort. sicaklık $\left({ }^{0} \mathrm{C}\right)$ & 6.2 & 7.6 & 11.7 & 15.7 & 22.8 & 27.7 & 21.6 & 14.0 & 8.6 \\
\hline & Ort. nispi nem(\%) & 68.8 & 74.3 & 58.9 & 49.7 & 38.0 & 35.3 & 50.5 & 48.1 & 50.8 \\
\hline & Top. Yağış (mm) & 82.5 & 100.8 & 79.0 & 24.3 & 10.3 & 0.7 & 58.8 & 7.9 & 25.3 \\
\hline
\end{tabular}

* Aylar; 1 Ocak, 2 Şubat, 3 Mart, 4 Nisan, 5 Mayıs, 6 Haziran, 10 Ekim, 11 Kasım, 12 Aralık

Kaynak : Anonim, 2015 [9]

Tablo 2. Deneme alanı topraklarının 0-20 cm derinlikteki bazı kimyasal özellikler

\begin{tabular}{|c|c|c|c|c|c|c|c|}
\hline Yillar & $\begin{array}{c}\text { Toprak } \\
\text { Derinliği } \\
\text { (cm) }\end{array}$ & $\begin{array}{c}\text { Suyla } \\
\text { Doygunluk } \\
(\%)\end{array}$ & pH & $\begin{array}{c}\text { Kireç } \\
(\%)\end{array}$ & $\begin{array}{c}\text { Yarayışlı } K \\
\left(\mathrm{~K}_{2} \mathrm{O}\right) \\
\left(\mathrm{kg} \mathrm{da}^{-1}\right)\end{array}$ & $\begin{array}{c}\text { Yarayışlı } P \\
\left(\mathrm{P}_{2} \mathrm{O}_{5}\right) \\
\left(\mathrm{kg} \mathrm{da}^{-1}\right)\end{array}$ & $\begin{array}{l}\text { Org. Mad. } \\
\text { (\%) }\end{array}$ \\
\hline 2013-2014 & $0-20$ & 66 & 7,63 & 27.3 & 137.1 & 2,69 & 2.01 \\
\hline 2014-2015 & $0-20$ & 68 & 7.54 & 28.1 & 221.7 & 2.49 & 1.74 \\
\hline
\end{tabular}

Denemede bitkisel materyal olarak 11 adet kırmızı mercimek çeşidi kullanılmıştır. Araştırma tesadüf blokları deneme desenine göre 4 tekrarlamalı olarak kurulmuştur. Her bir parsel 6 sıra X 5 m X $0.2 \mathrm{~m}$ olarak düzenlenmiştir. Deneme alanı önce pulluk ile $(18-20 \mathrm{~cm}$ derinlik) işlenmiş, ikinci sürüm ise goble disk ile (10-12 cm derinlikte) yapılmış, ardından tapan geçirilerek düzlenmiştir. Ekim deneme mibzeri ile yapılmış olup, 350 adet $/ \mathrm{m}^{2}$ tohum kullanılmıştır. Ekim öncesi yapılan toprak analiz sonuçlarına göre verilecek gübre miktarı saf olarak $6 \mathrm{~kg} / \mathrm{da} \mathrm{N}$ ve $6 \mathrm{~kg} / \mathrm{da} \mathrm{P}_{2} \mathrm{O}_{5}$ 'e tamamlanmıştır [10]. Verilecek toplam azot ve fosforun tamamı ekimle birlikte verilmiştir. Yabancı otlara karşı ilaçlı mücadelenin yanı sıra mekanik mücadele de yapılmıştır. İlaçlı mücadelede Tepraloxydim 50 g/l etkili maddeli herbisit $100 \mathrm{ml} / \mathrm{da}$ dozunda kullanılmıştır. Hasatta parsel kenarlarında yer alan 1'er sıra ile, parsel başı ve sonundan $0.5 \mathrm{~m}$ kenar tesiri olarak bırakılmıştır. Hasat olgunluğuna ulaşan bitkiler önce elle hasat edilmiş, daha sonra harmanlanarak parsel verimi elde edilmiştir. İncelenen özellikler ve yöntemler aşağıda verilmiştir [11].

Bitki Boyu (cm): Her parselden rastgele seçilen 10 bitkinin en üst noktası ile toprak yüzeyi arasındaki mesafe ölçülmüş, ortalamaları alınarak bitki boyu değeri bulunmuştur.

Çiçeklenme Gün Sayısı (gün) : Parseldeki bitkilerin% 50’sinin çiçeklendiği tarih belirlenmiş, çıkış tarihi ile çiçeklenme tarihi arasındaki süre gün olarak hesaplanmıştır.

1000 Tane Ăğırlı̆̆ı (g): Her parselden elde edilen tanelerden 100'erli dört grup sayılıp tartıldıktan sonra ortalamaları alınarak 100 tane ağırlığı değerleri bulunmuş, daha sonra 1000 tane ağırlı̆̆ına çevrilmiştir. 
Tane Verimi (kg/da): Her parselden elde edilen taneler tartılarak parsel verimi elde edilmiş, dekara çevrilerek tane verimi değerleri bulunmuştur.

Elde edilen veriler JUMP istatistiki paket program kullanılarak varyans analizi ve çoklu karşılaştırma testine tabi tutulmuştur.

\section{Bulgular}

Şanlıurfa koşullarında yetiştirilen kırmızı mercimek çeşitlerinin 2013-2014 ve 2014-2015 yetiştirme sezonu ile birleştirilmiş varyans analiz tablosu Tablo 3'de verilmiştir. Yapılan varyans analiz sonucuna göre her iki deneme yılında da çiçeklenme gün sayısı bakımından denenen çeşitler arasında \% 99 önem seviyesinde, farklılık bulunurken, her iki yılın birleşik analizinde ise yıl, çeşit ve yıl X çeşit \% 99 seviyesinde önemli bulunmuştur. Her iki deneme yılında da bitki boyu bakımından denenen çeşitler arasında \% 95 önem seviyesinde istatistiki farklılık gözlenirken, yapılan birleşik analizde ise, bitki boyu bakımından yıl, çeşit \% 99 önem seviyesinde, yıl X çeşit ise \% 95 seviyesinde istatistiki olarak önemli bulunmuştur. 1000 tane ağırlığı bakımından her iki deneme yılında ve birleşik analizde çeşitler arasında istatistiki olarak \% 99 önem seviyesinde farklılık tespit edilmiştir. Tane verimi bakımından yapılan varyans analiz sonucuna göre her iki deneme yılında da çeşitler arasında istatistiki olarak \% 99 önem seviyesinde farklılık tespit edilmiştir. Yapılan birleşik varyans analizinde yıl \% 95 önem seviyesinde, çeşit ve yıl X çeşit ise \% 99 önem seviyesinde istatistiki olarak önemli bulunmuştur (Tablo 3).

Tablo 3. Şanlıurfa koşullarında yetiştirilen kırmızı mercimek çeşitlerinin çiçeklenme süresi, bitki boyu, 1000 tane ağırlığı ve tane verimine ait 2013-2014, 2014-2015 yılları ve birleşik varyans analiz tablosu

\begin{tabular}{|c|c|c|c|c|c|}
\hline \multicolumn{6}{|c|}{$\begin{array}{c}\text { 2013-2014 Yetiştirme Sezonu } \\
\text { Kareler Ortalaması }\end{array}$} \\
\hline $\begin{array}{l}\text { Varyasyon } \\
\text { Kaynakları }\end{array}$ & SD & $\begin{array}{l}\text { Çiçeklenme } \\
\text { Süresi (gün) }\end{array}$ & Bitki Boyu (cm) & $\begin{array}{l}1000 \text { Tane } \\
\text { Ağırlığı (g) }\end{array}$ & $\begin{array}{l}\text { Tane Verimi } \\
\text { (kg/da) }\end{array}$ \\
\hline Tekerrür & 3 & 17.356 & 4.143 & 5.602 & 174.745 \\
\hline Çeşit & 10 & $35.2041^{* *}$ & $10.224^{*}$ & $59.951^{* *}$ & $5786.53 * *$ \\
\hline Hata & 30 & 4.0894 & 4.79224 & 1.5798 & 599.95 \\
\hline Genel & 43 & & & & \\
\hline $\mathrm{CV}$ & & 1.72 & 5.8 & 3.30 & 16.32 \\
\hline \multicolumn{6}{|c|}{0.05 seviyesinde önemli; **: 0.01 seviyesinde önemli } \\
\hline \multicolumn{6}{|c|}{$\begin{array}{c}\text { 2014-2015 Yetiştirme Sezonu } \\
\text { Kareler Ortalaması }\end{array}$} \\
\hline $\begin{array}{l}\text { Varyasyon } \\
\text { Kaynakları }\end{array}$ & SD & $\begin{array}{l}\text { Çiçeklenme } \\
\text { Süresi (gün) }\end{array}$ & Bitki Boyu (cm) & $\begin{array}{l}1000 \text { Tane } \\
\text { Ağırlığı (g) }\end{array}$ & $\begin{array}{l}\text { Tane Verimi } \\
\text { (kg/da) }\end{array}$ \\
\hline Tekerrür & 3 & 1.0530 & 3.5818 & 0.2890 & 241.608 \\
\hline Çeşit & 10 & $107.318 * *$ & $59.541^{*}$ & $60.2637 * *$ & $6067.25 * *$ \\
\hline Hata & 30 & 2.6030 & 15.3129 & 5.1771 & 123.46 \\
\hline Genel & 43 & & & & \\
\hline $\mathrm{CV}$ & & 1.24 & 8.46 & 5.98 & 8.09 \\
\hline \multicolumn{6}{|c|}{0.05 seviyesinde önemli; ${ }^{* *}$ : 0.01 seviyesinde önemli } \\
\hline \multicolumn{6}{|c|}{$\begin{array}{cc}\text { Birleşik Varyans Analiz Tablosu } \\
\text { Kareler Ortalaması }\end{array}$} \\
\hline $\begin{array}{l}\text { Varyasyon } \\
\text { Kaynakları }\end{array}$ & SD & $\begin{array}{l}\text { Çiçeklenme Süresi } \\
\text { (gün) }\end{array}$ & Bitki Boyu (cm) & $\begin{array}{l}1000 \text { Tane Ağırlığı } \\
\text { (g) }\end{array}$ & $\begin{array}{c}\text { Tane Verimi } \\
\text { (kg/da) }\end{array}$ \\
\hline Yil & 1 & $3462.5455^{* *}$ & $1597.1592 * *$ & 3.4037 & $3611.27^{*}$ \\
\hline Tekerrür & 3 & 5.8333 & 2.7987 & 1.91033 & 228.8833 \\
\hline Çeşit & 10 & $102.4773 * *$ & $49.39023 * *$ & $114.7949 * *$ & $12687.404 * *$ \\
\hline Y1lXÇeşit & 10 & $40.04545^{* *}$ & $20.37409 *$ & 5.41947 & $2196.375 * *$ \\
\hline Hata & 63 & 3.786 & 9.8089 & 3.4072 & 353.41 \\
\hline Genel & 87 & & & & \\
\hline $\mathrm{CV}$ & & 1.571 & 7.456 & 4.845 & 13.08 \\
\hline
\end{tabular}

Şanlıurfa koşullarında 2013-2014 ve 2014-2015 yetiştirme sezonlarında yetiştirilen kırmızı mercimek çeşitlerinin çiçeklenme gün sayısı ve bitki boyu parametrelerine ait ortalama değerleri Çizelge 
4'de verilmiş̧ir. Çizelge 4. incelendiğinde, 2013-2014 yetiştirme döneminde çiçeklenme gün sayısı 114,8 ile 122.5 gün arasında değişmiştir. İlk yıl en erken çiçeklenen çeşit Şakar, en geç çiçeklenen ise Çiftçi çeşidi olmuştur. İkinci deneme yılında ise çiçeklenme gün sayısı 120.3 ile 134.8 gün arasında değişmiş, en erken çiçeklenen Şakar, en geç çiçeklenen çeşit ise Yerli Kırmızı olmuştur. Her iki yılın ortalamasına göre en düşük çiçeklenme gün sayısı Şakar (117,6 gün) çeşidinde saptanmıştır. Birinci deneme yılının çiçeklenme gün sayısı, ikinci deneme y1lına göre daha düşük tespit edilmiştir. Bitki boyu değerleri 20132014 y1lında 35.9 ile $40.8 \mathrm{~cm}$ arasında, 2014-2015 y1lında 38.7-52.2 cm değişim göstermiştir. Her iki yılın ortalamasına göre ise, en yüksek bitki boyu değeri Seyran-96 çeşidinde belirlenirken, en düşük bitki boyu değeri Kafkas çeşidinde belirlenmiştir. İkinci deneme yılında bitki boyu değerleri, birinci deneme y1lına göre daha yüksek bulunmuştur (Tablo 4).

Tablo 4. Şanlıurfa koşullarında 2013-2014 ve 2014-2015 yetiştirme sezonlarında yetiştirilen kırmızı mercimek çeşitlerinin çiçeklenme gün sayısı ve bitki boyuna ait ortalama değerleri

\begin{tabular}{|c|c|c|c|c|c|c|}
\hline \multirow[t]{2}{*}{ Çeşitler } & \multicolumn{3}{|c|}{ Çiçeklenme Süresi (gün) } & \multicolumn{3}{|c|}{ Bitki Boyu (cm) } \\
\hline & 2013-2014 & 2014-2015 & ORT. & 2013-2014 & 2014-2015 & ORT. \\
\hline KAFKAS & $122.3 \mathrm{a}^{*}$ & $132.5 \mathrm{ab}$ & $127.4 \mathrm{ab}$ & $35.9 \mathrm{~d}$ & $38.7 \mathrm{~d}$ & $37.3 \mathrm{e}$ \\
\hline ÖZBEK & $120.5 \mathrm{ab}$ & $133.3 \mathrm{a}$ & $126.9 \mathrm{abc}$ & $37.2 \mathrm{bcd}$ & $43.9 \mathrm{bcd}$ & $40.6 \mathrm{bcd}$ \\
\hline ÇİFTÇİ & $122.5 \mathrm{a}$ & $133.3 \mathrm{a}$ & 127.9 a & 37.5 bcd & $46.5 \mathrm{abc}$ & 42.0 abc \\
\hline FIRAT & 119.0 bc & $132.8 \mathrm{a}$ & $125.9 \mathrm{bcd}$ & $38.5 \mathrm{ab}$ & $48.0 \mathrm{ab}$ & $43.8 \mathrm{a}$ \\
\hline SEYRAN & 115.5 d & $133.0 \mathrm{a}$ & 124.3 de & 37.9 a-d & $52.2 \mathrm{a}$ & $45.1 \mathrm{a}$ \\
\hline YERLİ KIRMIZI & $115.8 \mathrm{~d}$ & $134.8 \mathrm{a}$ & $125.3 \mathrm{~cd}$ & $40.8 \mathrm{a}$ & $48.0 \mathrm{ab}$ & $44.4 \mathrm{a}$ \\
\hline ÇAĞIL & $116.3 \mathrm{~cd}$ & $127.0 \mathrm{c}$ & $122.2 \mathrm{f}$ & $39.4 \mathrm{abc}$ & $48.6 \mathrm{ab}$ & $44.0 \mathrm{a}$ \\
\hline ALTINTOPRAK & $115.0 \mathrm{~d}$ & $120.8 \mathrm{~d}$ & $117.9 \mathrm{~g}$ & $36.3 \mathrm{~cd}$ & $41.4 \mathrm{~cd}$ & 38.9 de \\
\hline ŞAKAR & $114.8 \mathrm{~d}$ & $120.3 \mathrm{c}$ & $117.6 \mathrm{~g}$ & 38.0 a-d & 49. ab & $43.5 \mathrm{ab}$ \\
\hline TİGRİS & $116.8 \mathrm{~cd}$ & $133.5 \mathrm{a}$ & $125.2 \mathrm{~cd}$ & 36.4 bcd & $48.4 \mathrm{ab}$ & 42.4 abc \\
\hline EVİRGEN & $115.0 \mathrm{~d}$ & $130.3 \mathrm{~b}$ & 122.7 ef & $36.2 \mathrm{~d}$ & $44.3 \mathrm{bcd}$ & 40.2 cde \\
\hline LSD & 2.920 & 2.330 & 1.944 & 3.161 & 5.651 & 3.129 \\
\hline YIL ORT. & $117.6 \mathrm{~B}$ & $130.1 \mathrm{~A}$ & 123.9 & $37.7 \mathrm{~B}$ & $46.3 \mathrm{~A}$ & 42.0 \\
\hline Yillar LSD & \multicolumn{2}{|c|}{0.829} & & \multicolumn{2}{|c|}{1.334} & \\
\hline
\end{tabular}

*Aynı harf grubuna giren ortalamalar arasında 0.05 seviyesinde istatistiki olarak önemli farklılık yoktur.

Şanlıurfa koşullarında 2013-2014 ve 2014-2015 yetiştirme sezonlarında yetiştirilen kırmızı mercimek çeşitlerinin 1000 tane ağırlığı ve tane verimine ait ortalama değerleri Çizelge 5'de verilmiştir. Yapılan varyans analizi sonucuna göre, 1000 tane ağırlı̆̆ı değerleri 33.5 ile $46.10 \mathrm{~g}$ arasında belirlenmiştir. En yüksek 1000 tane ağırlığı değeri Şakar çeşidinde (46.10 g) belirlenirken, en düşük 1000 tane ağırlığı değeri ise Tigris çeşidinde (33.6 g) belirlenmiştir. En yüksek tane verimi 2013-2014 yılında Şakar çeşidinden (200.6 kg/da) elde edilirken, 2014-2015 yllında 186.2 kg/da ile yine Şakar çeşidinden elde edilmiştir. En düşük tane verimi ise her iki deneme yılında da Yerli Kırmızı çeşidinde (72.82 kg/da) saptanmıştır. Her iki yılın deneme ortalamasına göre, ikinci deneme yılı tane verimi değerleri, birinci deneme yılının değerlerinden daha yüksek bulunmuştur (Tablo 5). Her iki yılın ortalamasına bakıldığında en yüksek tane verimi Şakar çeşidinden elde edilirken, bunu Altıntoprak, Tigris ve Evirgen çeşitleri izlemiştir (Şekil 1).

Tablo 5. Şanlıurfa koşullarında 2013-2014 ve 2014-2015 yetiştirme sezonlarında yetiştirilen çeşitlerin 1000 tane ağırlığı ve tane verimine ait ortalama değerleri

\begin{tabular}{|c|c|c|c|c|}
\hline \multirow[t]{2}{*}{ Çeşitler } & \multirow[t]{2}{*}{1000 Tane Ağırlığı (g) } & \multicolumn{3}{|c|}{ Tane Verimi (kg/da) } \\
\hline & & $\begin{array}{l}2013- \\
2014\end{array}$ & 2014-2015 & ORT. \\
\hline KAFKAS & $37.79 \mathrm{~d}$ & 134.54 bcd & $168.67 \mathrm{bc}$ & $151.61 b^{*}$ \\
\hline ÖZBEK & $36.98 \mathrm{~d}$ & 112.90 cde & $129.89 \mathrm{~d}$ & $121.40 \mathrm{c}$ \\
\hline ÇİFTÇİ & 40.17 c & 142.42 bc & $125.30 \mathrm{~d}$ & 133.86 bc \\
\hline
\end{tabular}


Öktem AG.

\begin{tabular}{|c|c|c|c|c|}
\hline FIRAT-87 & $42.28 \mathrm{~b}$ & 103.49 de & 73.81 ef & $88.65 \mathrm{~d}$ \\
\hline SEYRAN-96 & $36.89 \mathrm{~d}$ & $167.91 \mathrm{ab}$ & $77.66 \mathrm{e}$ & 122.79 c \\
\hline YERLİ KIRMIZI & 39.98 c & 87.66 e & $57.98 \mathrm{f}$ & $72.82 \mathrm{~d}$ \\
\hline ÇAĞIL & $34.14 \mathrm{e}$ & 144.98 bc & $159.40 \mathrm{c}$ & $152.19 \mathrm{~b}$ \\
\hline ALTINTOPRAK & $36.70 \mathrm{~d}$ & 190.33 a & $181.30 \mathrm{ab}$ & $185.82 \mathrm{a}$ \\
\hline ŞAKAR & $46.10 \mathrm{a}$ & 200.58 a & $171.73 \mathrm{abc}$ & $186.16 \mathrm{a}$ \\
\hline TİGRİS & $33.55 \mathrm{e}$ & 183.69 a & 184.89 a & $184.29 \mathrm{a}$ \\
\hline EVİRGEN & $34.50 \mathrm{e}$ & 182.83 a & $179.78 \mathrm{ab}$ & $181.31 \mathrm{a}$ \\
\hline LSD & 1.844 & 35.372 & 16.046 & 18.784 \\
\hline YIL ORT. & 38.10 & $150.12 \mathrm{~A}$ & $137.31 \mathrm{~B}$ & 143.72 \\
\hline Yillar LSD & öd & \multicolumn{2}{|c|}{8.009} & \\
\hline
\end{tabular}

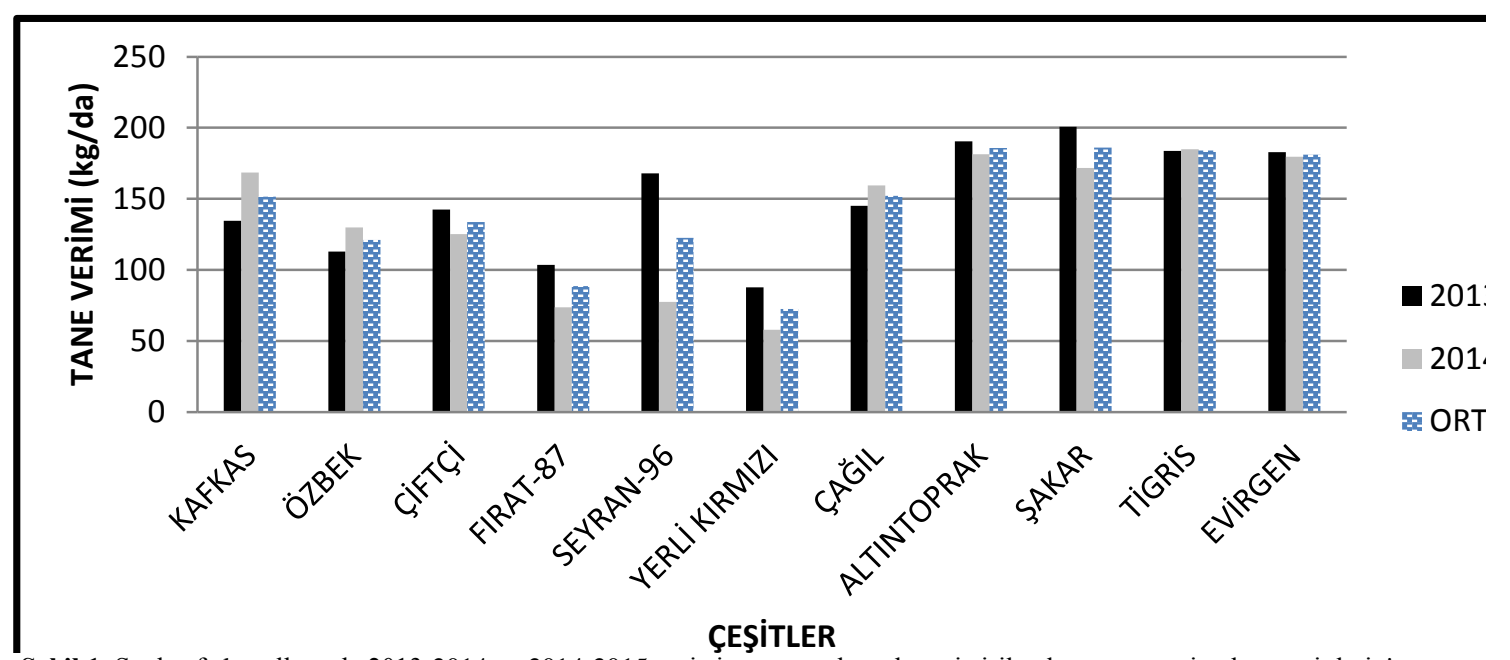

Şekil 1. Şanlıurfa koşullarında 2013-2014 ve 2014-2015 yetiştirme sezonlarında yetiştirilen kırmızı mercimek genotiplerinin tane verimine ait ortalama değerleri

\section{Tartışma ve Sonuç}

Şakar çeşidi her iki deneme yılında da en erken çiçeklenen çeşit olurken, 2013-2014 yetiştirme döneminde Çiftçi, 2014-2015 yetiştirme döneminde ise Yerli Kırmızı en geç çiçeklenen çeşit olmuştur. Düşük çiçeklenme gün sayısı ile erkencilik arasında doğru bir ilişki söz konusudur. Erken çiçeklenme Şanlıurfa gibi sıcak ve kurak bölgelerde önemli bir unsurdur. Nisan ayının ikinci yarısından itibaren Şanlıurfa'da sıcaklık hızlı bir şekilde yükselmekte ve sarı olum dönemi kısalarak, bitkilerin hızlı bir şekilde olgunlaşmasına neden olmaktadır. Erken çiçeklenen genotiplerde sarı olum dönemi uzadığı için verim artmakta ve diğer genotiplere göre avantaj sağlamaktadır. Nitekim her iki deneme yılında da erken çiçeklenen Şakar çeşidinin tane verimi değeri yüksek bulunmuştur (Tablo 5). Bunun yanı sıra, yağış miktarı ve sıcaklık da çiçeklenme gün sayısına önemli derecede etki etmektedir. Yağışın fazla, sıcaklığın düşük olması çiçeklenme süresini artırmaktadır. 2014-2015 deneme yılında, 2013-2014 deneme yılına göre toplam yağış miktarının fazla, sıcaklığın düşük olması çiçeklenme gün sayısını artırmıştır.

Denemenin ilk yılında en yüksek bitki boyu değeri Yerli Kırmızı çeşidinden elde edilirken, ikinci deneme yılında Seyran-96 çeşidinde en yüksek bitki boyu değerine ulaşılmıştır. Her iki yılın ortalama değerinde ise en uzun bitki boyuna sahip çeşit Yerli Kırmızı olmuştur. Bulgularımızı destekler nitelikte Seyran-96'nın en uzun, Kafkas çeşidinin ise en kısa bitki boyu değeri verdiği bazı araştırıcılar tarafından da bildirilmiştir [4]. Bitki boyu değeri çeşitlere, yetiştirme koşullarına ve iklime bağlı olarak değişiklik göstermektedir. Yağışın yeterli olduğu yıllarda bitki boyu değeri artarken, kurak yıllarda bitki boyu kısalmaktadır. Tablo 4'de belirtildiği gibi 2014-2015 deneme yılında, 2013-2014 deneme yılına 
göre daha fazla yağış kaydedildiğinden, bitki boyu değerleri daha yüksek bulunmuştur. Araştırma sonucunu destekler nitelikte bitki boyunun verimli topraklarda ve yeterli nemde en yüksek bitki boyu değeri verdiği bazı araştırıcılar tarafindan belirtilmiştir [12].

Her iki deneme yılında da en yüksek 1000 tane ağırlığı Şakar çeşidinden elde edilmiştir. 1000 tane ağırlı̆̆ının çeşit özelliği olduğu ve tane verimi üzerine etkisinin olumlu olduğu [14], çevrenin de 1000 tane ağırlığı üzerinde önemli bir etkisinin olduğu belirtilmektedir [5 , 13 ve 14]. Ayrıca farklı lokasyonlarda, 1000 tane ağırlığı değerlerinin aynı çeşitlerde bile farklı değerler alabildiği belirtilmiştir [6].

2013-2014 deneme yılı tane verimi değerleri, 2014-2015 deneme yılı tane verimi değerlerinden daha yüksek bulunmuştur. İkinci deneme yılında yağış miktarının fazla olmasına karşın, bitkinin istediği dönemlere göre dağılımı düzensiz olmuş, özellikle bakla bağlama dönemindeki düşük yağış miktarı verim ortalamasını düşürmüştür (Şekil 1). Araştırma sonuçlarını destekler nitelikte Siirt koşullarında çok aşırı sıcaklıklar ve düşük yağışın bitkideki çiçeklerin bakla bağlamasını engellediği, bu durumun tane verimini de olumsuz etkilediği belirtilmişsir [15]. Tane verimi değerleri 2013-2014 deneme yılında 87.66 ile $200.58 \mathrm{~kg} / \mathrm{da}$ arasında, 2014-2015 deneme yılında ise 57.98 ile $184.89 \mathrm{~kg} / \mathrm{da}$ arasında değişmiştir. Araştırma bulgularımıza yakın değerler bazı araştırıcılar tarafından belirtilmiştir. Harran ovası koşullarında 1995-1996 yıllarında 21 mercimek çeşidi ile yürütülen bir çalışmada; tane verimi değerlerinin 75.0-258.3 kg/da arasında değişim gösterdiği, en yüksek değerin Flip 897L (258.3 kg/da) hattından, en düşük değerin ise Flip 87-16L hattından $(75.0 \mathrm{~kg} / \mathrm{da})$ elde edildiği bildirilmiştir [13]. Siirt koşullarında yapılan bir çalışmada, bulgularımızdan daha düşük tane verimi değerleri elde edilmiş olup, en yüksek tane verimi $52.5 \mathrm{~kg} / \mathrm{da}$ ile Malazgirt-89 ve Kırmızı-51 çeşitlerinde, en düşük tane verimi ise $23.5 \mathrm{~kg} / \mathrm{da}$ ile Yerli Kırmızı çeşidinde saptanmıştır [15]. Diyarbakır'da yapılan bir araştırmada ise bulgularımızdan daha yüksek tane verimi değerleri (156.5 - $247 \mathrm{~kg} / \mathrm{da}$ ) bildirilmiştir [16]. Araştırmamızda orta sıralarda yer alan Kafkas ve Çiftçi çeşitlerinin Kahramanmaraş koşullarında en yüksek verim verdiği bildirilmiştir [17]. İklim ve toprak koşulları farklı olan lokasyonlarda çeşitlerin tane verimi değerleri de farklı olabilmektedir.

Araştırma sonuçlarına göre; Şanlıurfa koşullarında Şakar, Tigris, Altıntoprak ve Evirgen çeşitlerinden diğer çeşitlere göre daha yüksek verim elde edilmiştir. Bölgede en fazla ekim alanına sahip Fırat-86 ve Yerli Kırmızı çeşitlerinde ise her iki deneme yılında da en düşük verim değerleri belirlenmiştir. Fırat-86 ve Yerli Kırmızı çeşitleri özellikle yağışlı yıllarda aşırı boylandığından yatmakta ve verimleri düşük olmaktadır. Bu bağlamda Fırat-86 ve Yerli Kırmızı çeşitlerinin yüksek verimli ve yatmayan çeşitlerle yer değiştirmesi yerinde olacaktır.

\section{Kaynaklar}

[1] Şehirali S., Çiftçi, C.Y., Küsmenoğlu S., Ünver, Ö., Yorgancılar M., "Yemeklik Baklagiller Tüketim Projeksiyonları ve Üretim Hedefleri'” Türkiye Ziraat Mühendisliği IV. Teknik Kongresi 9-12 Ocak, s449-466. Ankara, 1995

[2] Özdemir S., "Yemeklik Baklagiller” Hasad Yaylncllık Ltd. Şti. 142 s975-8377-13-2, İstanbul, 2002

[3] Anonim, http://www.tuik.gov.tr. 2015 
[4] Biçer B.T., Şakar D., "Bazı kırmızı mercimek hat ve çeşitlerinde verim ve verim ögelerinin belirlenmesi” OMÜ Ziraat Fakültesi Dergisi, 22 (3); 292-296, 2007

[5] Erksine W., Ashkar F.E., "Rainfall and temperature effects on lentil (Lens culinaris Medik) seed yield in the Mediterranean enviroment” Journal of Agriculture Science (Cambridge) 121:347354, 1993

[6] Çölkesen M., Çokkızgın A., Turan B.T., Kayhan K., "Kahramanmaraş ve Şanlıurfa Koşullarında Değişik Kışlık Mercimek (Lens culinaris Medik) Çeşitlerinde Verim ve Kalite Özellikleri Üzerine Bir Araştırma” GAP IV. Tarım Kongresi 21-23 Eylül, s 826-833, Şanlıurfa 2005

[7] Erman M., "Van Ekolojik Koşullarında Mercimeğin Çeşit ve Adaptasyon Özellikleri Üzerinde Araştırmalar” Yüzüncü Yıl Üniversitesi, Fen Bilimleri Enstitüsü, Yüksek Lisans Tezi, 73s. Van, 1992

[8] Karadavut U., Erdoğan C., Özdemir S., Geçit H. H., "Küçük daneli bazı yabancı mercimek hatlarının Amik Ovası koşullarında kışlık olarak yetiştirilmesi üzerine bir araştırma” Türkiye 3. Tarla Bitkileri Kongresi 15-18 Kasım, Cilt III. s.407-412, Adana, 1999

[9] Anonim, “Devlet Meteoroloji İşleri Genel Müdürlüğü” www.dmi.gov.tr, 2015

[10] Arslan D., "Farklı Azot Dozlarının Mercimekte (Lens culinaris Medik.) Verim ve Bazı Tarımsal Karakterlere Etkisi” Harran Üniversitesi, Fen Bilimleri Enstitüsü, Yüksek Lisans Tezi, 58 s., Şanlıurfa, 2003

[11] Temel N., "Van ekolojik koşullarında farklı dozlardaki azotlu ve fosforlu gübreler ile bakteri aşılamasının (Rhizobium leguminosarum) Kışlık Kırmızı, Fırat-87 (Lens culinaris Medik) mercimek çeşidinin verim ve verim ögelerinin belirlenmesi üzerine bir araştırma” Yüzüncü Yıl Üniversitesi, Fen Bilimleri Enstitüsü , Doktora tezi, 96 s. Van, 1999

[12] Sell R., “Lentil Agronomic Information” www.ag.ndsu.edu/pubs/alt-ag/lentilir, 1993

[13] Aydoğan A., Karagül V., Bozdemir Ç., $\quad$ Kışlık kırmızı mercimek çeşitlerinin Orta Anadolu koşullarına adaptasyonu” GAP IV. Tarım Kongresi, 21-23 Eylül, s820-825, Şanlıurfa, 2005

[14] Alıcı S., "Harran Ovası koşullarında farklı mercimek (Lens culinaris Medik) çeşitlerinin morfolojik ve tarımsal karakterlerinin belirlenmesi üzerine bir araştırma” Harran Üniversitesi, Fen Bilimleri Enstitüsü, Yüksek Lisans Tezi, 40 s. Şanlıurfa,1997

[15] Yılmaz N., Kulaz H., Erman M., "Siirt ekolojik koşullarına uyabilecek mercimek (Lens culinaris Medik.) çeşitlerinin verim ve adaptasyonu üzerine araştırmalar” Yüzüncü Yıl Üniversitesi Ziraat Fakültesi Dergisi, 6 (2): 1-9. 1996

[16] Türk Z., Alkan Ş., Kılıç H., Polat T., "Güneydoğu Anadolu koşullarında yüksek verimli mercimek çeşitlerinin belirlenmesi” Harran Üniversitesi Ziraat Fakültesi Dergisi, 2 (4): 6570, 1998

[17] Çokkızgın A., Çölkesen M., Kayhan K., Aygan M., "Kahramanmaraş koşullarında değişik kışlık mercimek (Lens culinaris Medik) çeşitleri üzerine bir araştırma” Akdeniz Üniversitesi Ziraat Fakültesi Dergisi, 18(2): 285-291, 2005 